\title{
Characterization of Alkaliphilic, Surfactant Stable and Raw Starch Digesting A-Amylase from Bacillus subtilis Strain JS-16
}

\author{
Gopalakrishnan Menon, Kalpana Mody*, Sumitra Datta and Bhavanath Jha
}

Discipline of Marine Biotechnology and Ecology, Central Salt and Marine Chemicals Research Institute, Council of Scientific \& Industrial Research (CSIR), Gujarat, India

\begin{abstract}
An alkali-thermophilic and surfactant stable a-amylase was obtained from Bacillus subtilis strain JS-16, isolated from sludge samples of a soda ash industry, located on west coast of Gujarat. It was active over a wide temperature range $\left(30^{\circ} \mathrm{C}-80^{\circ} \mathrm{C}\right)$ exhibiting optimum activity at $50^{\circ} \mathrm{C}$ and $\mathrm{pH} 9.0$. Unique feature of this amylase was two-fold enhancement of activity in SDS. Three-step purification yielded 15.16 -fold purified enzyme with specific activity of $13.5 \mathrm{U} / \mathrm{mg}$ proteins. $\mathrm{K}$ and $\mathrm{V}$ were $10 \mathrm{mg} / \mathrm{ml}$ and $0.2 \mu \mathrm{mol} / \mathrm{min} / \mathrm{ml}(11.56 \mu \mathrm{mol} / \mathrm{min} / \mathrm{mg}$ protein) respectively. Enzyme activity enhanced with $\mathrm{Fe}^{3+}$ but was strongly inhibited by $\mathrm{Hg}^{2+}$ ions. The amylase hydrolyzed $12 \%$ raw wheat starch and $5 \%$ corn starch granules after $12 \mathrm{~h}$ incubation. Surfactant stability, alkaliphilic nature, activity under wide temperature range and hydrolyses of raw starch makes this amylase a promising candidate for liquid detergent and starch industry.
\end{abstract}

Keywords: Alkaline amylase; Alkaliphilic; Bacillus subtilis

\section{Introduction}

a-Amylases (E.C. 3.2.1.1) produced by plants, animals and microbes, hydrolyze a-1-4 glycosidic linkages in starch to dextrin, maltotriose, maltose and glucose. Amylases have been extensively used in food, fermentation, textile and paper industries with $30 \%$ production worldwide and 25\% share in the enzyme market. Microbial amylases are preferred for industrial production considering the economics, faster production, wide range of operation parameters and minimum space requirements [1-4]. Demand for extremozymes with a blend of unique catalytic properties for specific biochemical processes is ever increasing. Extremozymes from alkaliphiles have found their applications in tanneries, paper and pulp, laundry, detergents and waste water treatment Bacillus sp. (B. subtilis, B. stearothermophilus, $B$. licheniformis and B. amyloliquefaciens), a dominant and omnipresent representative of Phylum Firmicutes has been widely used source of microbial amylase $[5,6]$. Alkaline amylases are best suited as detergent additives and for starch saccharification in food and textile industries [7].

Present study deals with production of alkaline amylase by an alkaliphilic Bacillus subtilis strain JS-16 isolated from a soda ash industry located in west coast of Gujarat, India. Further, it was purified and characterized for its unique properties that make it a potential biochemical catalyst for various industries.

\section{Materials and Methods}

\section{Isolation and screening of amylolytic bacteria}

The bacterium, Bacillus subtilis JS-16, reported in current study was isolated from sodic sludge ( $\mathrm{pH}$ 9.24) sampled from west coast of Gujarat (21.8619 N 72.2775 E). Modified Horikoshi I medium (in g/l; glucose 10.0 , peptone 5.0 , yeast extract $5.0, \mathrm{~K}_{2} \mathrm{HPO}_{4} 1.0, \mathrm{MgSO}_{4} .7 \mathrm{H}_{2} \mathrm{O} 0.2$, agar 20.0, $\mathrm{pH}$ adjusted to 9.0 with sterilized saturated $\mathrm{NaOH}$ solution) was used as an alkaline basal medium for isolation and storage. Purified colonies were streaked on M9 medium containing soluble starch (in $\mathrm{g} / \mathrm{l}$; soluble starch 5.0, Yeast extract 2.0, $\mathrm{NaCl} 2.5, \mathrm{NH}_{4} \mathrm{Cl} 5.0, \mathrm{KH}_{2} \mathrm{PO}_{4}$ 15.0, $\mathrm{Na}_{2} \mathrm{HPO}_{4} 30.0, \mathrm{MgSO}_{4}$ 0.25, agar 20.0, final $\mathrm{pH}$ adjusted to 9.0). After incubation at $37^{\circ} \mathrm{C}$ for $96 \mathrm{~h}$, plates were flooded with Lugol's Iodine. Based on zone of clearance, strain JS-16 was selected for further study.

\section{Bacterial identification and phylogenetic analysis}

Morphological, physiological and biochemical characteristics of JS-16 was studied according to Bergey's Manual of Determinative Bacteriology [8]. Fatty Acid Methyl Ester (FAME) analysis was performed (MIDI Sherlock Microbial Identification System). For molecular identification genomic DNA was extracted by standard chloroform-isoamyl alcohol method [9]. PCR amplification of 16S rRNA was performed using forward and reverse primers as $8 \mathrm{f}(\mathrm{fD} 1) 5^{\prime}$ AGA GTT TGA TCC TGG CTC AG-3' and 1495r (rP2) 5'-ACG GCT ACC TTG TTA CGA CTT $-3^{\prime}$ respectively [10]. Reaction mixture for PCR amplification contained 10X PCR buffer $5 \mu \mathrm{l}, 200 \mathrm{mM}$ dNTPs $5 \mu \mathrm{l}$, $2.5 \mathrm{U}$ Taq DNA polymerase, $20 \mathrm{pM}$ of each primers (Sigma, India) and $50 \mathrm{ng}$ of bulk DNA. Amplification was performed in a thermal cycler (Bio-Rad MyCycler, Thermal cycler, California, USA) for an initial denaturation at $94^{\circ} \mathrm{C}$ for 4 min followed by 35 cycles of $94^{\circ} \mathrm{C}$ for $1 \mathrm{~min}$, $58^{\circ} \mathrm{C}$ for $1 \mathrm{~min}$ and $72^{\circ} \mathrm{C}$ for $2 \mathrm{~min}$ and a final extension at $72^{\circ} \mathrm{C}$ for 5 min. Purified PCR product was sequenced for BLAST analysis [11]. $16 \mathrm{~S}$ rRNA gene sequence was deposited in GenBank with accession number GQ280086. Phylogenetic analysis was done by MEGA 4.1 [12] software and tree was constructed using neighbor-joining method [13].

\section{Amylase production}

Culture was inoculated to $500 \mathrm{ml}$ broth of M9 medium containing soluble starch and incubated at $37^{\circ} \mathrm{C}$ for $96 \mathrm{~h}$. Culture supernatant after centrifugation (8000X $\mathrm{g}$ for $10 \mathrm{~min}$ ) was used as crude enzyme.

\footnotetext{
*Corresponding author: Dr. Kalpana Mody, Discipline of Marine Biotechnology and Ecology, Central Salt and Marine Chemicals Research Institute, Council of Scientific and Industrial Research (CSIR), Gijubhai Badheka Marg, Bhavnagar 364 002, Gujarat, India, Tel: +91-278-2561354; Fax: +91-278-2567562; E-mail: khmody@csmcri.org
}

Received July 25, 2014; Accepted August 14, 2014; Published August 21, 2014

Citation: Menon G, Mody K, Datta S, Jha B (2014) Characterization of Alkaliphilic, Surfactant Stable and Raw Starch Digesting A-Amylase from Bacillus subtilis Strain JS-16. J Microb Biochem Technol S8: 002. doi:10.4172/1948-5948.S8-002

Copyright: $\odot 2014$ Menon G, et al. This is an open-access article distributed under the terms of the Creative Commons Attribution License, which permits unrestricted use, distribution, and reproduction in any medium, provided the original author and source are credited 


\section{Effect of carbon sources}

Amylase production was carried out using soluble starch, maltose, dextrin and sugar cane bagasse. M9 medium supplemented with $0.5 \%$ of the above mentioned carbon source was inoculated with the culture and incubated at $37^{\circ} \mathrm{C}$ for $96 \mathrm{~h}$.

\section{Amylase assay}

Amylase activity was determined at $50^{\circ} \mathrm{C}$ for $15 \mathrm{~min}$ in $20 \mathrm{mM}$ Tris$\mathrm{HCl}$ buffer ( $\mathrm{pH}-9.0)$ by measuring the release of reducing sugar from starch using Dinitrosalicylic acid (DNS) method [14]. In blank, enzyme was added after addition of DNS reagent. The absorbance was taken at $540 \mathrm{~nm}$. One unit of amylase activity was defined as the amount of enzyme that produced $1 \mu \mathrm{mol}$ of maltose equivalent per minute under specified conditions.

\section{Protein estimation}

Protein concentration was determined by Folin phenol method [15] with bovine serum albumin as standard. Protein content of the chromatographic fractions was measured at $280 \mathrm{~nm}$.

\section{Purification of Amylase}

Ammonium sulfate precipitation and dialysis: Crude amylase was precipitated with $70 \%$ saturation of ammonium sulfate and kept overnight at $4^{\circ} \mathrm{C}$. Precipitate was centrifuged and dissolved in minimum volume of $20 \mathrm{mM}$ Tris- $\mathrm{HCl}$ buffer ( $\mathrm{pH}$ 9.0). Dialysis was done using dialysis tubing (Sigma, D-0655).

Anion exchange chromatography: Prior to equilibration, the DEAE-cellulose (SRL, Mumbai, India) was activated by suspending in $0.5 \mathrm{M} \mathrm{HCl}$, degassed for $20 \mathrm{~min}$, and washed with distilled water till it was acid free followed by treatment with $0.5 \mathrm{M} \mathrm{NaOH}$ and finally washed with distilled water. This process was repeated thrice to activate the support. The support is loaded on the column $(2 \mathrm{~cm} \times 18 \mathrm{~cm})$ and was equilibrated with $20 \mathrm{mM}$ Tris- $\mathrm{HCl}$ buffer of $\mathrm{pH}$ 9.0. The ammonium sulfate precipitated and dialyzed enzyme solution was loaded on the column and eluted with a stepwise concentration gradient of sodium chloride $(0,0.25,0.5,0.75$ and $1 \mathrm{M} \mathrm{NaCl})$ in the same buffer. The fractions, each $3 \mathrm{ml}$, were collected at a flow rate of $0.6 \mathrm{ml} / \mathrm{min}$. Protein concentration and amylase activity of each fraction was determined. Active fractions were pooled.

Size exclusion chromatography: Pooled fraction $(5 \mathrm{ml})$ from ion exchange chromatography was loaded to a Sephadex-G-100 (GE Healthcare, Uppsala, Sweden) column $(1.25 \mathrm{~cm} \times 25 \mathrm{~cm})$ preequilibrated with $20 \mathrm{mM}$ of Tris- $\mathrm{HCl}$ buffer $(\mathrm{pH} 9.0)$ and then eluted with the same buffer. Fractions of $2 \mathrm{ml}$ each were collected at a flow rate of $19 \mathrm{ml} / \mathrm{h}$. Protein concentration and amylase activity of each fraction was determined. Active fractions were pooled, concentrated by lyophilization and checked for purity by SDS-PAGE.

\section{SDS-PAGE and zymogram analysis}

SDS-PAGE (10\%) [16] was run for determining molecular mass of the purified enzyme. Standard molecular mass markers (Genei, Bangalore, India) used were, phosphorylase b $(97.4 \mathrm{kDa})$, bovine serum albumin $(66 \mathrm{kDa})$, ovalbumin $(43 \mathrm{kDa})$, carbonic anhydrase $(29$ $\mathrm{kDa})$ and lactoglobulin $(18.4 \mathrm{kDa})$. Silver staining was done to view the protein bands [9].

Zymogram analysis was done by running native PAGE (10\%). A $3 \%$ agarose plate was prepared into which $0.5 \%$ soluble starch was incorporated. After electrophoresis, the native PAGE gel was laid over the agarose gel and incubated at $40^{\circ} \mathrm{C}$ for $3 \mathrm{~h}$. The agarose gel after incubation was overlaid with Lugol's Iodine solution to visualize the band.

\section{Effect of $\mathrm{pH}$ and temperature on amylase activity}

Optimum $\mathrm{pH}$ for amylase activity was determined at $50^{\circ} \mathrm{C}$ for 15 min using different buffers viz. citrate buffer (6.0), Mc Levine buffer (7.0), Tris- $\mathrm{HCl}$ buffer (8.0-9.0) and glycine- $\mathrm{NaOH}$ buffer (10.0-11.0). Stability of the purified enzyme with respect to varying $\mathrm{pH}(6.0-10.0)$ was determined by incubating in respective buffer for $30 \mathrm{~min}$.

The optimum temperature for amylase activity was determined by incubating the assay system from $30^{\circ} \mathrm{C}$ to $80^{\circ} \mathrm{C}$. Stability of the purified enzyme with respect to temperature was also determined by incubating the enzyme from $30^{\circ} \mathrm{C}$ to $80^{\circ} \mathrm{C}$ at $\mathrm{pH} 9.0$ for $30 \mathrm{~min}$.

\section{Effect of additives and surfactants}

Amylase activity was determined in presence of different cations $\left(\mathrm{Ca}^{2+}, \mathrm{Co}^{2+}, \mathrm{Hg}^{2+}, \mathrm{Mn}^{2+}, \mathrm{Fe}^{2+}, \mathrm{Mg}^{2+}, \mathrm{Cu}^{2+}, \mathrm{Cd}^{2+}, \mathrm{Zn}^{2+}\right.$ and $\left.\mathrm{K}^{+}\right)$at $5 \mathrm{mM}$ concentration. Effect of additives like $\beta$ Mercaptoethanol, EDTA and PMSF (5 mM), SDS, Triton X-100, Tween-80, commercial detergents (Surf Excel and Tide) $\{1 \%(\mathrm{w} / \mathrm{v})\}$ was checked by pre-incubating the enzyme for $30 \mathrm{~min}$.

\section{Kinetic studies}

The kinetic properties of amylase were determined using varying concentration of soluble starch. $\mathrm{K}_{\mathrm{m}}$ and $\mathrm{V}_{\max }$ values were calculated by Lineweaver Burk double reciprocal plot.

\section{Raw starch hydrolysis by crude amylase}

Raw corn, wheat and potato starch granules $(10 \mathrm{mg})$ were separately mixed with $5 \mathrm{ml}$ of the crude enzyme and final volume made up to $10 \mathrm{ml}$ with $20 \mathrm{mM}$ Tris- $\mathrm{HCl}$ buffer ( $\mathrm{pH} 9.0)$. The reactions were incubated at $50^{\circ} \mathrm{C}$ in a shaking $(100 \mathrm{rpm})$ water bath. Sample aliquots were collected after 4, 8, 12, 16, 20 and $24 \mathrm{~h}$ for the estimation of reducing sugars [14]. Degree of hydrolysis of raw starch (Rh) was defined by the formula: $\mathrm{Rh}$ $(\%)=(\mathrm{A} 1 / \mathrm{A} 0) \times 100$, where $\mathrm{A} 1$ was - amount of sugar in the supernatant after hydrolysis and A0 was the initial amount of raw starch [17].

\section{Results and Discussion}

\section{Bacterial identification}

Strain JS-16 was found to be Gram-positive, motile, rod shaped, exopolysaccharide producer (Figure 1A). The biochemical characteristics of JS-16 are given in Table 1. Isolate JS-16 produced six alkaliphilic extracellular enzymes namely, amylase (Figure 1B), caseinase, pectinase, lipase, xylanase and gelatinase. It was strongly inhibited by Chloramphenicol, Ciprofloxacin and Erythromycin. JS-

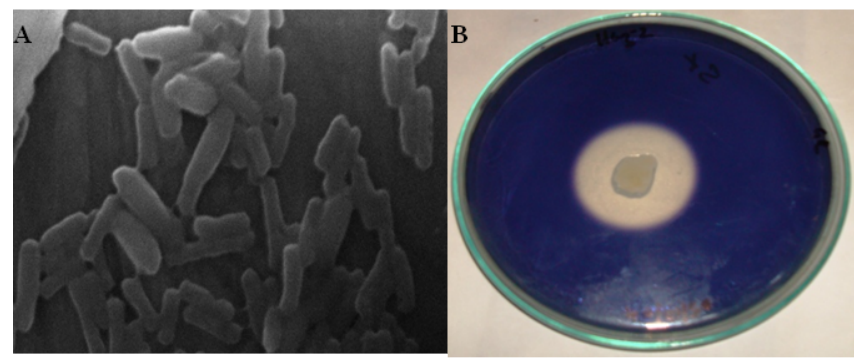

Figure 1: (A) SEM image of JS-16 (B) Plate assay showing a zone of clearance. 
Citation: Menon G, Mody K, Datta S, Jha B (2014) Characterization of Alkaliphilic, Surfactant Stable and Raw Starch Digesting A-Amylase from Bacillus subtilis Strain JS-16. J Microb Biochem Technol S8: 002. doi:10.4172/1948-5948.S8-002

\begin{tabular}{|c|c|}
\hline Tests & Results \\
\hline Colour, size & Creamy round medium sized \\
\hline Gram reaction & Gram positive \\
\hline Motility & + \\
\hline Catalase & - \\
\hline Oxidase & + \\
\hline Indole & - \\
\hline MR & - \\
\hline VP & - \\
\hline Simmons citrate & - \\
\hline Amylase & + \\
\hline Pectinase & + \\
\hline Gelatinase & + \\
\hline Lipase & + \\
\hline Caesinase & + \\
\hline Phenylalanine & - \\
\hline Urease & - \\
\hline $\mathrm{H} 2 \mathrm{~S}$ production & - \\
\hline Nitrate reduction & - \\
\hline Arginine & + \\
\hline Lysine & - \\
\hline Ornithine & + \\
\hline Dextrose & - \\
\hline Fructose & $+/-$ \\
\hline Galactose & $+/-$ \\
\hline Lactose & - \\
\hline Maltose & $+/-$ \\
\hline Mannose & + \\
\hline Sucrose & + \\
\hline Xylose & + \\
\hline
\end{tabular}

Table 1: Morphological and biochemical characteristics of Bacillus subtilis JS-16.

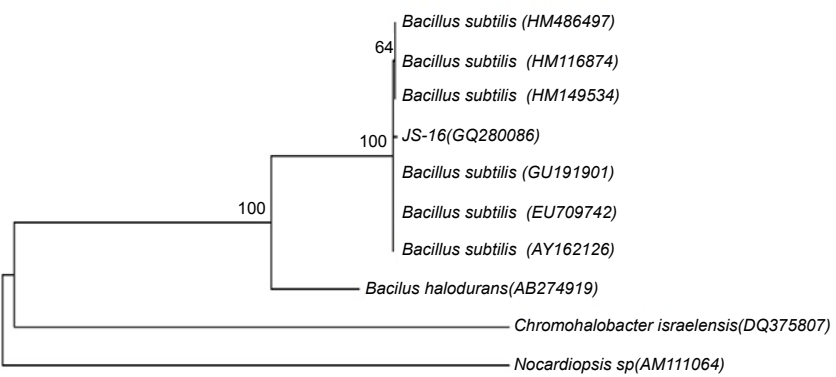

0.05

Figure 2: Phylogenetic tree showing taxonomic position of JS-16. Figures within brackets represent GenBank accession numbers.

16 could tolerate broad $\mathrm{pH}$ range (7.0-12.0) with optimum growth at $\mathrm{pH} 9.0$ and 5\% salt concentration. FAME analysis of JS-16 showed a Similarity Index (SI) of 0.75 with Bacillus subtilis accounted from RTSBA library (Sherlock software). BLAST search of 16 S rRNA gene sequence (1424 bp) showed $99 \%$ homology with that of Bacillus subtilis strain W1. The phylogenetic tree (Figure 2) shows taxonomic position of isolate JS-16.

\section{Amylase production and purification}

Soluble starch was the best carbon source for amylase production followed by dextrin and maltose (Figure 3). Sugar cane bagasse was not a good inducer. Bacillus sp. strain TSCVKK produced optimal amylase with $1 \%$ dextrin [18]. The three-step purification yielded 15.16 fold purification of amylase with $4.13 \%$ yield and specific activity of 13.5 Units/mg of protein (Table 2). 1.7 fold purification and 74\% yield was reported from Bacillus subtilis WB600 recombinant amylase [19].

\section{SDS-PAGE and zymogram analysis}

The purification homogeneity assayed from native page revealed two bands of equal intensities corresponding to molecular mass of about 99 and $87 \mathrm{kDa}$. Two zones of clearance in zymogram supported the trends obtained in native PAGE. Correspondingly, four bands of molecular mass of about 35, 42, 48 and $58 \mathrm{kDa}$ were obtained in the SDS-PAGE (Figure 4). Two bands with amylase activity in zymogram might be a possible explanation for the hetero-dimeric forms. Bacillus sp. A 3-15 amylase also reported two forms with molecular mass of 86 and $60.5 \mathrm{kDa}$ after partial purification [20]. Similar results were

\begin{tabular}{|c|c|c|c|c|c|c|}
\hline Enzyme & $\begin{array}{c}\text { Total } \\
\text { vol (ml) }\end{array}$ & $\begin{array}{c}\text { Total } \\
\text { Protein } \\
\text { (mg) }\end{array}$ & $\begin{array}{c}\text { Total } \\
\text { activity } \\
\text { (units) }\end{array}$ & $\begin{array}{c}\text { Specific } \\
\text { activity Units/ } \\
\text { mg protein }\end{array}$ & $\begin{array}{c}\text { Fold } \\
\text { purification }\end{array}$ & \%Yield \\
\hline Crude & 500 & 620 & 540 & 0.89 & 1 & 100 \\
\hline $\begin{array}{c}\text { Ammonium sulfate } \\
\text { precipitation }\end{array}$ & 45 & 61.2 & 81 & 1.33 & 1.5 & 15.05 \\
\hline $\begin{array}{c}\text { DEAE column } \\
\text { chromatography }\end{array}$ & 27 & 9.45 & 36 & 3.85 & 4.33 & 6.75 \\
\hline Gel permeation & 10 & 1.73 & 23.3 & 13.5 & 15.16 & 4.31 \\
\hline
\end{tabular}

Table 2: Purification of amylase isolated from Bacillus subtilis JS 16.

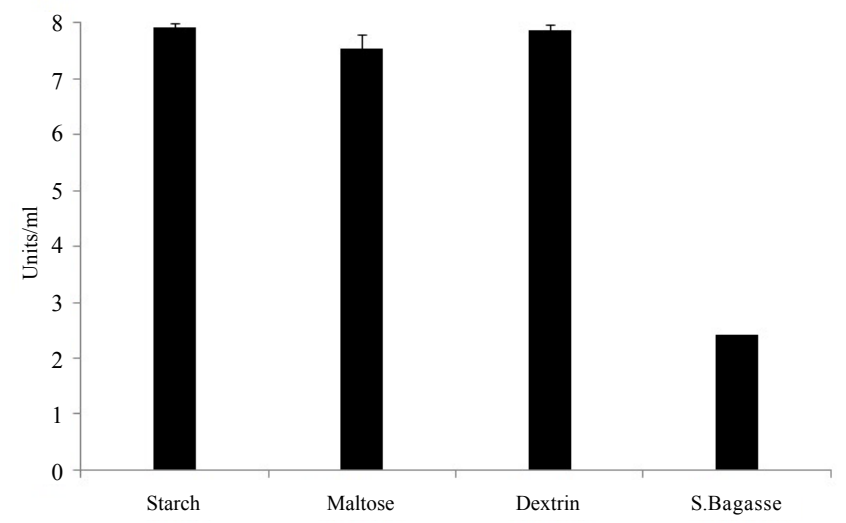

Figure 3: Effect of different carbon sources on amylase production where $\mathrm{S}$ Bagasse is Sugarcane Bagasse.

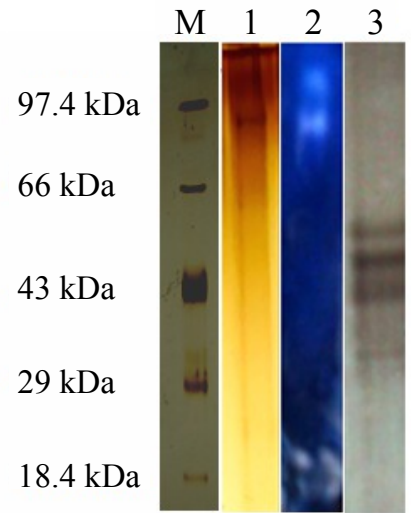

Figure 4: Native and SDS-PAGE of purified amylase where $M$ denotes molecular markers Lane 1 native PAGE of purified amylase 2 Zymogram of the purified amylase 3 SDS-PAGE of purified amylase. 

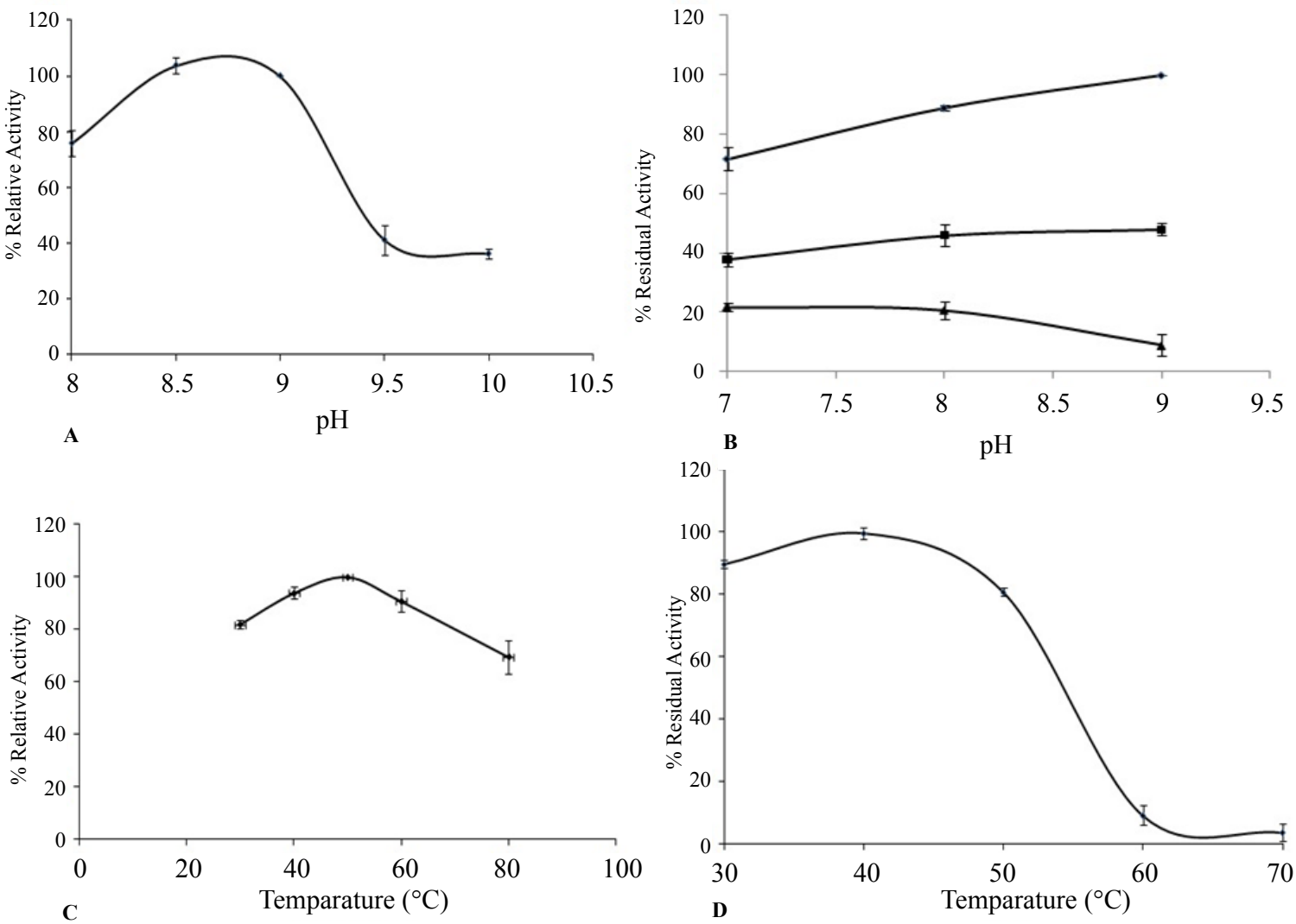

Figure 5: (A) Effect of $\mathrm{pH}$ on amylase activity (B) Effect of $\mathrm{pH}$ on amylase stability. (Solid diamond) denotes activity at 0 min; (Solid square) denotes activity after $30 \mathrm{~min}$ incubation; (Solid triangle) denotes activity after 60 min incubation. (C) Effect of temperature on amylase activity (D) Thermostability of amylase after preincubating for $30 \mathrm{~min}$.

also reported from halophilic bacterial species Chromohalobacter sp. TVSP101 [21].

\section{Effect of $\mathrm{pH}$ and temperature on amylase activity}

Bacillus subtilis strain JS-16 amylase exhibited good activity from pH 8.0 (76.0\% relative activity) to 9.0 with optimum at pH 9.0 (Figure $5 \mathrm{~A}$ ). An optimum $\mathrm{pH}$ of 6.0 was reported by amylase from Bacillus subtilis AX20 [22]. After 30 min incubation at $\mathrm{pH} 9.0$, approximately $48 \%$ residual activity was observed, which was drastically reduced after 60 min incubation (Figure 5B).

JS-16 amylase exhibited good activity from $20^{\circ} \mathrm{C}-80^{\circ} \mathrm{C}$ with optimum at $50^{\circ} \mathrm{C}$. Moreover, $70 \%$ relative activity was seen at $80^{\circ} \mathrm{C}$ (Figure 5C). Thermo stability test showed that about $80 \%$ residual activity was observed at $50^{\circ} \mathrm{C}$ which was drastically decreased at $60^{\circ} \mathrm{C}$ (Figure 5D). This trend is in accordance to that of Nesterenkonia sp. strain $\mathrm{F}$ amylase [23].

\section{Effect of additives and surfactants on amylase activity}

$\mathrm{Fe}^{3+}$ ions enhanced amylase activity while $\mathrm{Hg}^{2+}$ strongly inhibited it. 55\% residual activity was seen with $\mathrm{Ca}^{2+}$ ions (Figure 6A). JS-16 amylase was $\mathrm{Ca}^{2+}$ ions independent similar to that from Bacillus subtilis AX20 [22] and in contrast to Bacillus sp. strain TSCVKK amylase [18]. Considerable activity was observed with PMSF and $\beta$-mercaptoethanol (Figure 6B). Enhanced activity in PMSF was contradictory to a thermostable alkaline $\alpha$-amylase from Bacillus sp. A 3-15 that was inhibited by $3 \mathrm{mM}$ PMSF [20]. EDTA did not affect amylase activity indicating it as metal independent. SDS enhanced amylase activity by two-fold. In Triton X-100 and Tween 80, residual activity of $62 \%$ and $72 \%$ respectively was retained. Nesterenkonia sp. strain F amylase retained $90 \%$ activity on incubation with $0.1-0.5 \%$ SDS [23]. Similarly $82 \%$ and $80 \%$ activity was exhibited by Bacillus sp. A 3-15 and Bacillus sp. PN5 respectively, with $1 \%$ SDS $[20,24] .90 \%$ activity was retained by Bacillus sp. strain TSCVKK amylase with $0.1 \%$ Triton X-100 and Tween 80 [18]. Present study reports massive enhancement of amylase activity with SDS and greater stability in surfactants (Tween 80 and Triton X-100) making it a potential candidate for detergent market. However, when surf and tide were used as additives, amylase retained a very low residual activity of 27 and $13 \%$ respectively. Sensitivity to oxidants present in the detergents should be a plausible explanation for reduction in amylase activity. Increase of $\alpha$-amylase activity in the presence of SDS might be the first of its kind to be reported.

\section{Kinetic studies}

$\mathrm{Km}$ value was $10 \mathrm{mg} / \mathrm{ml}$ and the Vmax was $0.2 \mathrm{~g} \mu \mathrm{mol} / \mathrm{min} / \mathrm{ml}$ (11. $56 \mu \mathrm{mol} / \mathrm{min} / \mathrm{mg}$ protein). Values of kinetic parameters differ with different substrates or assay conditions, and thus, the $\mathrm{Km}$ value of amylase from JS-16 was well within the range of other $\alpha$-amylases $(0.35-11.66 \mathrm{mg} / \mathrm{ml})$ [25].

\section{Raw starch hydrolysis by crude amylase}

JS-16 amylase hydrolyzed raw wheat and corn starch granules at the rate of $12 \%$ and $5 \%$ respectively, after $12 \mathrm{~h}$ incubation (Figure 7 ). Significant hydrolysis of potato starch was not obtained. The degradation 

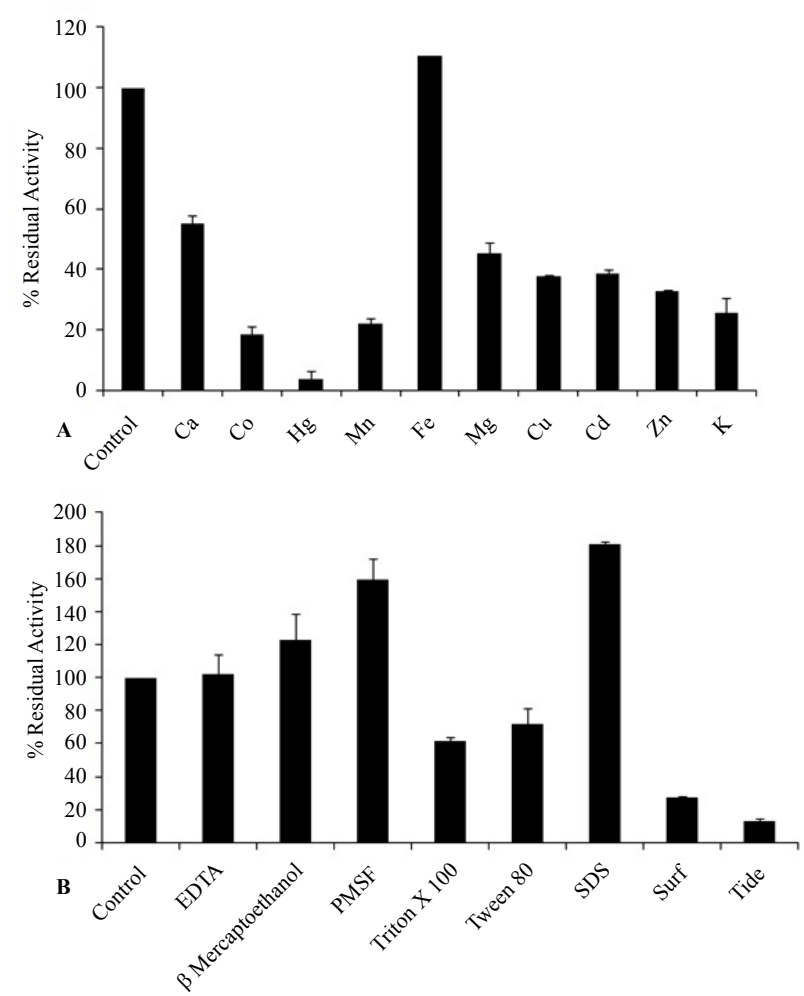

Figure 6: (A) Effect of metal ions on amylase activity. (B) Effect of organic additives, surfactants and commercial detergents on amylase activity.

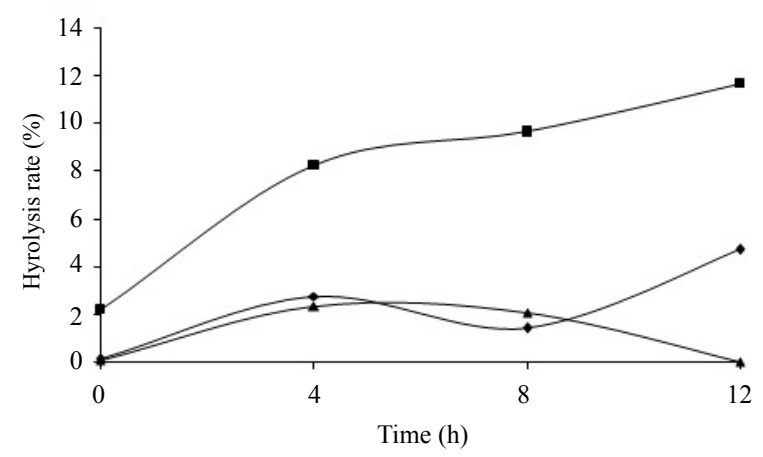

Figure 7: Hydrolysis at $50^{\circ} \mathrm{C}$ of raw corn (Solid diamond), wheat (Solid square) and potato (Solid triangle) starch granules by crude amylase.

rates of corn, wheat and potato starch granules at $1 \%$ concentration were $63.2 \%, 56.4 \%, 48.6 \%$ at $12 \mathrm{~h}$, respectively from Bacillus sp. YX-1 amylase [17]. A Ca ${ }^{2+}$ dependent thermostable $\alpha$-amylase from Bacillus sp. I-3 hydrolyzed raw potato starch granules in a temperature range of $60-90^{\circ} \mathrm{C}$ at a concentration of $12.5 \%$ in $12 \mathrm{~h}$ [26]. Similarly Bacillus sp. GRE1 amylase hydrolyzed starch granules from wheat, corn and tapioca at $40-70^{\circ} \mathrm{C}$, with $50 \%$ degradation of starch granules after $12 \mathrm{~h}$ at $70^{\circ} \mathrm{C}$ without $\mathrm{Ca}^{2+}$ supplementation $[27,28]$. Halophilic $\alpha$-amylase from Nesterenkonia sp. strain $\mathrm{F}$ hydrolyzed raw wheat and corn granules at the rate of $38 \%$ and $20 \%$ after $48 \mathrm{~h}$ incubation, respectively $[23,29]$.

\section{Conclusion}

The Bacillus subtilis strain JS-16 isolated from the sludge samples of a soda ash industry in Gujarat produced $\alpha$-amylase with promising properties. Activity of amylase at an alkaline $\mathrm{pH}$, over a broad range of temperature and stimulation in the presence of SDS, are the key properties which could make this isolate a potential candidate for its use as a source of amylase suitable especially for the liquid detergent industry where SDS is largely used as surface active agent.

\section{Acknowledgement}

Authors are thankful to Council of Scientific and Industrial Research, New Delhi for financial support to Gopalakrishnan and Sumitra Datta.

\section{References}

1. Burhan A, Nisa U, Gokhan C, Omer C, Ashabil A, Osman G (2003) Enzymatic properties of a novel thermostable, thermophilic, alkaline and chelator resistant amylase from an alkaliphilic Bacillus sp.isolate ANT-6. Process Biochem 38: 1397-1403.

2. Gupta R, Gigras P, Mohapatra H, Goswami VK, Chauhan B (2003) Microbia a-amylases: a biotechnological perspective. Process Biochem 38: 1599-1616.

3. Rao MB, Tanksale AM, Ghatge MS, Deshpande VV (1998) Molecular and biotechnological aspects of microbial proteases. Microbiol Mol Biol Rev 62 597-635.

4. Sivaramakrishnan S, Gangadharan D, Nampoothiri KM, Soccol CR, Pandey A (2006) a-Amylases from microbial sources-an overview on recent developments. Food Technol Biotechnol 44: 173-184.

5. Hashim SO, Delgado O, Hatti-Kaul R, Mulaa FJ, Mattiasson B (2004) Starch hydrolysing Bacillus halodurans isolates from a Kenyan soda lake. Biotechno Lett 26: 823-828.

6. Horikoshi K (1996) Alkalophiles-from an industrial point of view. FEMS Microbio Rev 18: 259-270.

7. Kim TU, Gu BG, Jeong JY, Byun SM, Shin YC (1995) Purification and Characterization of a Maltotetraose-Forming Alkaline (alpha)-Amylase from an Alkalophilic Bacillus Strain, GM8901. Appl Environ Microbiol 61: 3105-3112.

8. Holt JD (1994) Bergey's Manual of Determinative Bacteriology, 9thed. Williams and Wilkins, Baltimore.

9. Sambrook J, Fritsch EF, Maniatis T (2001) Molecular Cloning: A Laboratory Manual. 3rd ed. Cold Spring Harbor, NY: Cold Spring Harbor Laboratory.

10. Weisburg WG, Barns SM, Pelletier DA, Lane DJ (1991) 16S ribosomal DNA amplification for phylogenetic study. J Bacteriol 173: 697-703.

11. Altschul SF, Gish W, Miller W, Myers EW, Lipman DJ (1990) Basic local alignment search tool. J Mol Biol 215: 403-410.

12. Tamura K, Dudley J, Nei M, Kumar S (2007) MEGA4: Molecular Evolutionary Genetics Analysis (MEGA) software version 4.0. Mol Biol Evol 24: 1596-1599.

13. Saitou N, Nei M (1987) The neighbor-joining method: a new method for reconstructing phylogenetic trees. Mol Biol Evol 4: 406-425.

14. Miller G (1959) Use of dinitrosalicylic acid reagent for determination of reducing sugars. Anal Chem 31: 426-428.

15. Lowry OH, Rosebrough NJ, Farr AL, Randall RJ (1951) Protein measurement with the Folin phenol reagent. J Biol Chem 193: 265-275.

16. Laemmli UK (1970) Cleavage of structural proteins during the assembly of the head of bacteriophage T4. Nature 227: 680-685.

17. Liu XD, Xu Y (2008) A novel raw starch digesting alpha-amylase from a newly isolated Bacillus sp. YX-1: purification and characterization. Bioresour Technol 99: 4315-4320.

18. Kiran KK, Chandra TS (2008) Production of surfactant and detergent-stable halophilic, and alkalitolerant alpha-amylase by a moderately halophilic Bacillus sp. Strain TSCVKK. Appl Microbiol Biotechnol 77: 1023-1031.

19. Liu Y, Lu F, Chen G, Snyder CL, Sun J, et al. (2010) High-level expression, purification and characterization of a recombinant medium-temperature alphaamylase from Bacillus subtilis. Biotechnol Lett 32: 119-124.

20. Arikan B (2008) Highly thermostable, thermophilic, alkaline, SDS and chelator resistant amylase from a thermophilic Bacillus sp. isolate A3-15. Bioresour Technol 99: 3071-3076. 
Citation: Menon G, Mody K, Datta S, Jha B (2014) Characterization of Alkaliphilic, Surfactant Stable and Raw Starch Digesting A-Amylase from Bacillus subtilis Strain JS-16. J Microb Biochem Technol S8: 002. doi:10.4172/1948-5948.S8-002

21. Prakash B, Vidyasagar M, Madhukumar MS, Muralikrishna G, Sreeramulu K (2009) Production, purification, and characterization of two extremely halotolerant, thermostable, and alkali-stable a-amylases from Chromohalobacter sp. TVSP101. Process Biochem 44: 210-215.

22. Najafi MF, Deobagkar D, Deobagkar D (2005) Purification and characterization of an extracellular alpha-amylase from Bacillus subtilis AX20. Protein Expr Purif 41: 349-354

23. Shafiei M, Ziaee A, Amoozegar MA (2010) Purification and biochemical characterization of a novel SDS and surfactant stable, raw starch digesting, and halophilic a-amylase from a moderately halophilic bacterium, Nesterenkonia sp. strain F. Process Biochem 45: 694-699.

24. Saxena RK, Dutt K, Agarwal L, Nayyar P (2007) A highly thermostable and alkaline amylase from a Bacillus sp. PN5. Bioresour Technol 98: 260-265.

25. Najafi MF, Kembhavi A (2005) One step purification and characterization of an extracellular a-amylase from marine Vibrio sp. Enzyme Microb Technol 36 : 535-539.

26. Goyal N, Gupta JK, Soni SK (2005) A novel raw starch digesting thermostable a-amylase from Bacillus sp. I-3 and its use in the direct hydrolysis of raw potato starch. Enzyme Microb Technol 37: 723-734.

27. Haki GD, Anceno AJ, Rakshit SK (2008) Atypical Ca2+-independent, rawstarch hydrolysing a-amylase from Bacillus sp. GRE1: characterization and gene isolation. World J Microbiol Biotechnol 24: 2517-2524.

28. Pathak A, Rathod MG (2013) Bioprospecting an alkaline ecosystem of Lonar Lake for novel alkaline protease producer. Innovative Research in Chemistry 1: 22-26.

29. Antony CP, Kumaresan D, Hunger S, Drake HL, Murrell JC, et al. (2013) Microbiology of Lonar Lake and other soda lakes. ISME J 7: 468-476.
This article was originally published in a special issue, Biomaterials: Down Stream Processing handled by Editor. Dr. Peter Kilonzo, University of Western Ontario, Canada 